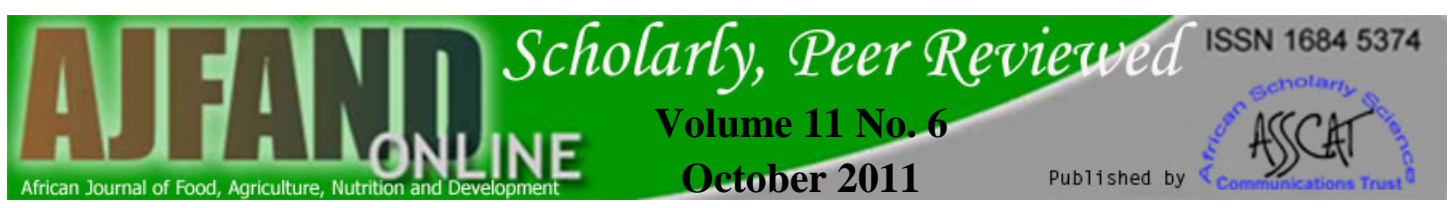

\title{
THE PRIMACY OF TRUST IN THE SOCIAL NETWORKS AND LIVELIHOODS OF WOMEN AGRO-ENTREPRENEURS IN NORTHERN TANZANIA
}

\author{
Mehta $\mathbf{K}^{1^{*}}$, Semali $\mathbf{L}^{2}$ and A Maretzki ${ }^{3}$
}

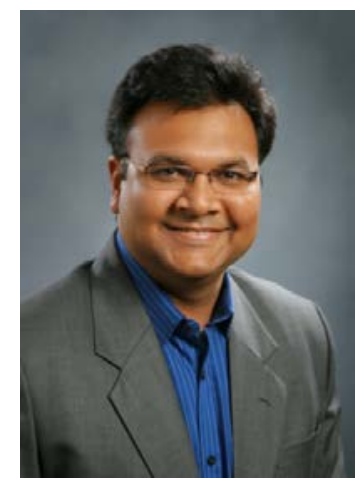

Khanjan Mehta

*Corresponding Author Email: khanjan@engr.psu.edu

${ }^{1}$ Humanitarian Engineering and Social Entrepreneurship (HESE) Program, College of Engineering, The Pennsylvania State University, University Park, PA 16802.

${ }^{2}$ College of Education, The Pennsylvania State University, University Park, PA 16802.

${ }^{3}$ Department of Food Science, College of Agricultural Sciences, The Pennsylvania State University, University Park, PA 16802. 


\section{ABSTRACT}

This paper describes the primacy of trust in the social networks and livelihoods of rural Tanzanian women engaged in agro-entrepreneurial activity. The importance of trust emerged from a study of the "who you know" social and economic network knowledge systems of these enterprising women in Moshi, Tanzania and the role cell phones play within their networks. The nature of the women's agricultural businesses and their perceptions of the characteristics of women business leaders and cooperative group members were also studied. The objective of the study was to identify opportunities for developing innovative cellphone-based applications that link smallscale farmers and other entrepreneurs to markets, thus enabling these entrepreneurs to utilize, strengthen and expand their social and economic networks. A complementary goal was to identify the characteristics of women who are likely to successfully champion new entrepreneurial ventures. Three data collection techniques were employed: (1) a Personal Digital Assistant (PDA) survey, (2) structured interviews; and (3) focus group interviews. There were 26 women participants in this network study - all living in multi-ethnic areas in, or near, the town of Moshi. Each participant was the proprietor of a stall selling agricultural products in one of the three town markets. A total of 92 relationships were described by these 26 women. The majority of the women primarily used cell phones in their business communication and considered cell phones crucial to their businesses. The women valued long-term relationships with over $70 \%$ of the business relationships described by the women having lasted for more than one year. The study revealed that these relationships were based very strongly on trust and respect. This primacy of trust in these networks was further validated by the individual interviews and focus group discussions. Loyalty and the maintenance of inter-personal relationships are more important than price in these women's business-related decision-making. The findings suggest the importance of building trust while expanding "who you know" networks to create social and economic capital in rural African communities. The pervasiveness and importance of cell phones in these communities raises the possibility of employing this technology to create value by harnessing social capital and expanding social networks. An entrepreneurial venture called WishVast emerged from this study and is described in this paper. WishVast is a cellphone-based system that allows individuals to interact within an expanded, geographically dispersed social network - and as a result, it enables traditionally isolated individuals to connect, communicate and coordinate with a large number of potential clients.

Keywords: social networks, trust, cell phones, entrepreneurship 


\section{INTRODUCTION}

This paper discusses findings from a social network study conducted in 2008 in Northern Tanzania that led to the development of a model illustrating the primacy of trust in the dynamic interdependence of social networks, cell phones and entrepreneurial success [1]. This paper, titled "Trust, Cell phones, Social Networks and Agricultural Entrepreneurship in East Africa: A Dynamic Interdependence" provides the conceptual framework and literature review that sets the stage for the research endeavor discussed in this paper. The proposed model suggests that the most compelling opportunities for sustainable value creation and self-determined development in Africa exist at the intersection of cell phones, social networks and entrepreneurship, with the necessary condition that trust, the glue that holds these elements together, is present. The conceptual paper culminated with a case-study that illustrated how trust dynamics related to cell phones and social networks might have supported the sustainability and scalability of a nutribusiness cooperative in Kenya. The nutribusiness goal was to improve the livelihoods of women and the nutritional status of children in rural communities. The Kenya experience suggested that understanding social networks is especially important for developing successful agricultural cooperatives. The Tanzanian study referenced in this paper was conducted to better understand the existing social networks of rural women agroentrepreneurs in Northern Tanzania prior to the initiation of a new agriculture-based entrepreneurial venture. The three objectives of this pilot research study were:

1. Identify and describe nodes (actors) within the social networks of women agro-entrepreneurs who sell agricultural commodities in urban markets in Northern Tanzania

2. Explore the women's access to, facility with, and use of cell phones in their agro-businesses and identify opportunities for strengthening their enterprises.

3. Explore the women's perceptions about value-addition and characteristics of women business leaders and collaborators.

\section{Data Sources and Methods}

To meet the objectives outlined above, this study employed three data collection techniques: (1) a PDA survey, (2) structured interviews; and (3) focus group interviews. There were 26 women participants in this network study — all lived in multi-ethnic areas in or near the town of Moshi and each was the proprietor of a stall selling agricultural products in one of the three town markets. Moshi, located at the foot of Mount Kilimanjaro, has a population of approximately 900,000 and a vibrant agricultural market economy. The town has a public transportation system that links the town to nearby semi-urban and semi-rural areas through small vans called daladalas. These vans provided the study participants with convenient access to municipal services and to their workplaces.

\section{PDA Survey}

The PDA survey data was conducted by trained data collectors. They used PDAs (hand-held computers) equipped with a custom-developed application that allowed each respondent to answer questions related to the attributes and structures of their

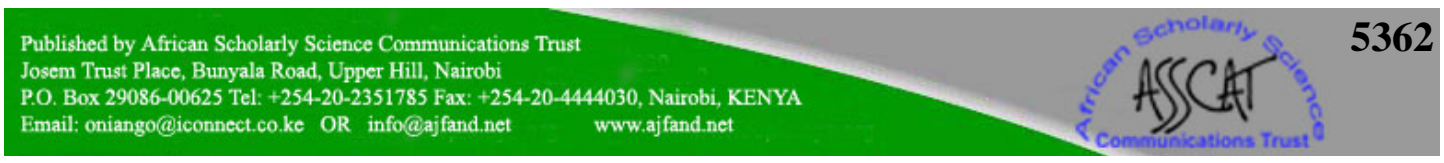


social networks. This form of social research survey employed a set of questions or statements with scaled response options provided on the PDA screen [2]. Subsequently, the responses were aggregated and quantitative data (totals, percentages etc.) were derived for analysis and presentation. The questionnaire was divided into three parts: (a) items that collected general participant information, (b) semi-structured questions that targeted participants' social network relationships and (c) demographic questions. The 46 semi-structured questions were repeated for each person identified by a respondent as being a part of her social network, up to a maximum of 5 persons per respondent. A total of 92 relationships were thus described by the 26 women interviewed. Some of the questions related to trust and summary of those participant responses are presented and discussed in this paper.

\section{Structured Interviews}

A structured interview protocol was designed for this study to provide a one-on-one interview session for each respondent [3]. The structured interview protocol consisted of nine questions that focused on the nature of the woman's business, how the business was initiated and conducted, how she sourced the produce she sold, her perspective on leadership qualities of good business leaders and the kind of people with whom she would and would not engage in business transactions. Since the researchers were unsure about the level of proficiency in reading and writing on the part of the participants, an interviewer posed the questions and recorded the replies of the respondents in Kiswahili. The responses were subsequently translated into English.

\section{Focus Group Interviews}

A focus group interview was used to elicit responses from three groups of 6-9 women participants, each group representing a different market location. The assumption was that because some of the participants were friends and worked at the same market, their combined responses might provide a richer data set. The group session was conducted in a relaxed setting to elicit natural dialogue among a small group of women involved with selling agricultural products in one of the three major open air markets in town. This group interview was conducted by an experienced faculty member.

Focus groups, a form of qualitative research, were chosen to complement the structured PDA survey and interviews. More importantly, the group setting allowed individuals to use the ideas of others as cues to more fully elicit their own views [4]. The focus group session lasted about an hour and addressed the question of how a group of women like themselves might initiate a value-added food processing operation. Questions were asked in an interactive group setting where participants were free to talk with each other. The specific questions included: (1) Who could provide the leadership to organize market women and help them develop a collaborative business plan? (2) How would they get the money they would need? (3) To whom would they go for technical help? (4) To whom would they sell their product? And (5) what problems might such a group encounter? One of the team members took notes during each focus group discussion. A total of three focus group 
discussions, each lasting about two hours, were conducted over the three days of the pilot study.

\section{Conceptions of Trust as Observed from the Network Data}

The PDA survey was administered to 26 participants. The responses to trust-related questions are summarized in Table 1 . Most (81\%) of the women had completed seven years of school, 8\% had completed nine years (Form 2) and $11 \%$ had completed twelve years (Form 4.) A majority (54\%) of the women primarily used cell phones in their business communication, whereas somewhat fewer (46\%) used face-to-face communication (including travel) as their primary means of business-related communication. Cell phones, while not the primary way of conducting all business communication, were, nevertheless considered important to carrying out business by a vast majority (96\%) of these women agro-entrepreneur respondents. Somewhat less than half (44\%) of the women's business relationships involved buying produce, $10 \%$ involved selling, bartering and lending money. Nearly half $(48 \%)$ of the business relationships involved personal favors between the individuals involved. The most common individuals in the social networks of these women were wholesalers, farmers and street restaurant vendors, but respondents also mentioned public transport operators, immediate family, security guard, stall setup person, cell phone person, hired house-help, tour guide, district councilor, teacher and church leader. Over $70 \%$ of the business relationships described by the women had lasted for more than one year. Nearly all of their identified business contacts were trusted (96\%) and respected $(100 \%)$ by the study participants.

Despite the fact that they were selling produce in the same market, women often did not know each other well and were not organized. They did not use formal credit, but instead, borrowed money from family members. The survey data, as well as the interviews, suggest that the women value long-term business relationships and base these relationships on trust and respect. Loyalty and the maintenance of inter-personal relationships are more important than price in these women's business-related decision-making. The data indicating that women judged their business relationships to be with individuals who were honest (95\%) and reliable (90\%) further support the salience of trust in business relationships. The women had confidence in nearly all (97\%) of the people with whom they conducted business, believing that there was nothing to be unsure or afraid of in their relationship with these business contacts. The women respondents also felt they could rely on most (84\%) of their business contacts to follow through on promises and commitments.

About half the women made one or two new business contacts through their existing relationships, while one-third of the women did not make any new contacts and leveraged only their existing relationships to expand their businesses. The fact that most of the women's business relationships were built over a long period of time, underscores the challenge of rapidly building trust and social capital. Despite the perception of a growing popularity of SACCOS (Savings and Credit Co-operative Societies) for access to microfinance, only $10 \%$ of the women in the study were associated with a cooperative. 
The women respondents indicated that a majority of their business contacts were not like (similar to) themselves. They indicated that they were willing to take the same level of risk as about half of their business partners. The women's business contacts were overwhelmingly perceived as open-minded about ideas and opinions different than their own. This characteristic of openness was also reflected in innovativeness being a desired quality of a good leader. Although about one-third of the respondents competed with their business contacts, they also sought business advice from them. Two-thirds of the respondents' contacts were considered good business leaders and the women respected them and engaged in business activities with them. Respondents were particularly open to the idea of innovation in the area of value addition to the agricultural commodities they sold.

Among the 92 individuals with whom the 26 women respondents conducted business, $70 \%$ were known to be dependable. Most respondents (56\%) were in business relationships that benefitted from the fact that both individuals were located in the same market, 52\% noted that their business relationships were beneficial to them because the person was of the same religion, and $45 \%$ of the respondents felt that their business relationship benefitted from the fact that both individuals were women. Approximately 33\% of the business relationships assessed by the respondents were with people who had been observed to influence the opinions of other, and to be between individuals who speak the same language and have the same level of education. Less than $25 \%$ of the respondents' business relationships were expected to benefit because both individuals were age-mates. These findings suggest that in establishing business relationships, women may be more likely to benefit from a relationship with an older person who can serve as mentor. However, women who work in the same market and attend the same church as their business associates are likely to know each other, and therefore depend upon, and trust one another.

\section{Observations from individual interviews}

\section{Sourcing of produce}

A majority of the women respondents purchased their produce either directly from a farmer or from a wholesaler who had previously purchased from a farmer. Although a majority of the women were price-conscious, the quality of the produce being offered and their existing relationship with the seller were more important than price. When produce was in short supply, women were more likely to purchase from a specific person. When produce was plentiful, although women preferred to purchase from a specific person, the quality of the seller's produce was the deciding factor. Preference was also given to persons who delivered produce on credit and deferred payment until after the produce was sold. Polite and respectful communication was valued by all respondents.

An interesting anecdote shed light on the way business is conducted. One woman described her purchase of a large bag of dried beans from a farmer. When she opened the bag, she discovered that two buckets of beans were rotten and/or damaged and could not be sold. She did not demand a refund or replacement from the farmer and did not view the transaction as a business loss despite the fact that she lost money on

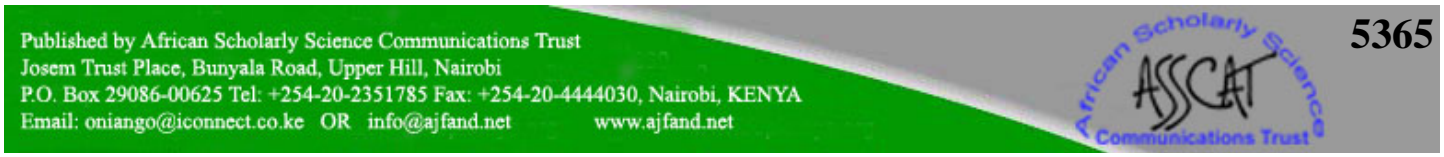


her purchase of beans from this farmer. It is speculated that she would not purchase beans from this farmer in the future, but it is also possible that this was a person she had been successfully doing business with for some time and that she had reason to maintain a trusting relationship with this farmer in the future. This is simply a speculation and not a statement with any objective evidence.

\section{Characteristics of good business leaders}

The characteristics named, in decreasing order of importance, were: trustworthiness, being a good listener, possessing business acumen, talking to everyone nicely, being kind to everyone and providing advice, innovativeness, being a role model for the group, attending meetings regularly, and not being greedy or egotistic. Women's anecdotes describing good business leaders strongly reinforced the characteristics ascribed to a good leader. Trustworthiness was the first thing mentioned by more than half the participants, often before the data collector had completed the question. Every respondent mentioned trustworthiness at some point during her interview.

\section{Characteristics of good cooperative group members}

The characteristics named, in decreasing order of importance, were attendance and punctuality at meetings, industriousness, the ability to maintain confidentiality, collaborativeness, business experience, self-discipline, selflessness, and not being argumentative. It is particularly interesting to note that some of the women were concerned about competitive advantage and did not want members to reveal their group's business secrets. Another observation that emerged from this set of interviews was the perception that members who attended meetings regularly were seen as trustworthy.

\section{Characteristics of individuals the women would not work with}

The characteristics named, in decreasing order of importance, were laziness, not being trustworthy, not being experienced, not attending meetings, being hypocritical, swindling others, lying, being a corrupt person, someone who dislikes the respondent, uses abusive language, engages in unpleasant conduct, is consistently late, or is a drunkard. The respondents' anecdotes strongly reinforced these characteristics and priorities. About half the women specifically mentioned that they had forgiven people who had cheated them, but added that they would not work with these individuals again.

\section{Observations from focus groups}

\section{Financial observations}

Many women expressed doubt in their ability to organize themselves and to develop a business plan. They wanted to know each other better and develop trust before working together. Women cited financial hardship and low wages when employed as the most common factors leading them to start their own businesses. Women reported borrowing between TSH. 7,000 and 200,000 (US \$5 - \$150) from family members to start their produce-selling businesses. Many women had to take several consecutive loans to manage their cash flow. Many women started their agro-business with very small quantities of produce and gradually scaled up to a "bucketful of fruits". These 
entrepreneurs did not have established credit records although all of them indicated that they had successfully repaid their family loans. Sending their children to school and providing them a better life were the most important motivators and outcomes for the women. This observation is consistent with studies indicating that a woman's disposable income is more likely than that of her husband to be used to improve the education, health and quality of life of their children.

\section{Marketing observations}

Except for displaying their products and interacting with individual customers who passed their booth, women did not think about "marketing” their produce. When the women heard of Kenyan women being able to serve samples of their nutritious porridge mix to potential customers, they felt this was a good idea and suggested that they might be able to do the same. While the women used their cell phones extensively for their businesses, they did not specifically mention using them for marketing their produce.

\section{Ideas for value-addition}

A common challenge identified by women was food spoilage due to the inability to sell their perishable produce quickly enough. They did not know how to extend the shelf-life of perishable fruits and vegetables or how to convert them to a shelf-stable form. A respondent talked about how tomatoes are in excess supply during the harvest season. At this time prices are low and most of the tomatoes rot before they are sold. Women expressed a desire to learn how to preserve excess fruits and vegetables in season and sell them later when the price goes up. Another respondent narrated her story of adding tablets to bags of corn to prevent insect damage. She reportedly was able to store the corn for six months and sell it to a prison for $70 \%$ more than the price she had paid. There was a consensus that the storage of dried grains and beans was the simplest and easiest form of value addition for these popular commodities, but they were not sure how they might be able to accomplish this.

While discussing their need for technical support to be able to develop, process and market a shelf-stable grain-based food product such as the one being marketed by the Kenya nutribusiness cooperative, one woman asked about the dehulled maize used in its porridge mix. She had heard that "processing" of grains removed valuable nutrients. This is a message widely used to encourage the consumption of unpolished (brown) rice and the use of whole grain flour for baking. However, it misses the scientific point that excessive fiber is undesirable in the diets of infants and young children.

When the women brainstormed what crops they might consider for value addition, they talked about avocados, rosella (hibiscus flowers) and dried beans as well as storage of grain that could be purchased when there was excess in the market and sold when the price rose seasonally. The discussion focused exclusively on converting single foods into a more shelf-stable or convenient form or storing it to await more favorable pricing. The idea of creating a unique multi-ingredient or "branded" product with enhanced nutritional value did not emerge from the women during focus group discussions.

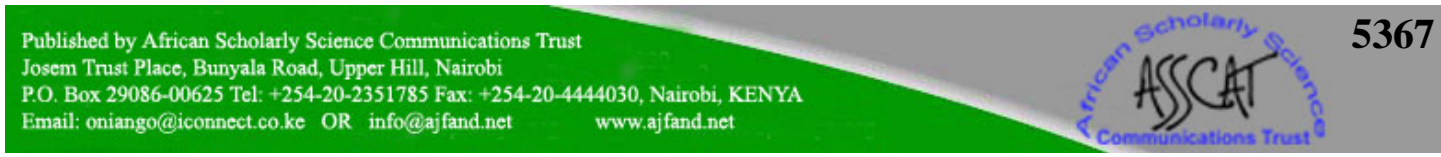


The women recognized the potential of selling different forms of a single commodity; an opportunity they lack at present. For example, they believed tomatoes could be sold fresh, dried, canned or pickled. They liked the concept of value-addition, which in their experience, would be especially attractive for crops like avocados that sustain high seasonal losses. The only example of a multi-commodity item mentioned by the women was a tomato-based sauce that the women felt would be purchased as a convenience food by the street restaurant purveyors with whom they had established business relationships.

\section{Discussion on the opportunities and implications for the use of cell phones}

A basic law of economics, called the law of one price, dictates that the price of a product should not differ between any two markets by more than the transport cost between them. This law assumes that agents have the necessary price information to engage in optimal trade. However, strong theoretical and empirical evidence suggests that price dispersion is pervasive and persistent. The study observed that in Tanzania, the price of commodities varied greatly from market to market. Much, and in some markets, most, of the observed dispersion stems from information costs - consumers' costs of acquiring information about vendors, and/or vendors costs of transmitting information to consumers [5]. There is a need for tools that provide real-time information to detect and exploit violations of the law of one price. Cell phone-based applications that link small-scale farmers and other entrepreneurs to input-output markets are examples of such tools.

This study helped understand the requirements, opportunities and challenges of a 'social network support system' that can enable cooperatives and their champions to utilize, strengthen and expand their social networks. It was discovered in Tanzania that individuals tend to do business with members of a geographically-bound social network in part because isolation limits their options. The observations gathered during this study and experiences in Kenya and Tanzania led to the development of an entrepreneurial venture called WishVast: Building Trust and Social Capital Using Cell phones. WishVast is a cellphone-based system that allows individuals to interact with a larger and geographically dispersed social network - and as a result it enables traditionally isolated individuals to connect, communicate and coordinate with a large number of clients [6]. Like Ebay, WishVast monitors members' business practices by supporting the awarding of points by both members in the business transaction. Over time, these points add up and create a cumulative business trustworthiness score. WishVast reflects the practicalities of leveraging social networks for economic value in developing communities. The intricacies, social dynamics and inequalities of labor hiring practices and macadamia nut supply chains were studied to validate the WishVast system [7].

In Kenya, WishVast has been field-tested for one scenario - connecting jobseekers to employers with ad-hoc jobs. For this application, the initial users were individuals looking for (mostly agriculture-related) contract jobs and individuals/enterprises that offer contract jobs. The job solicitations and offers were facilitated by WishVast and both employee and employer were able to rate each other at the end of the transaction. 


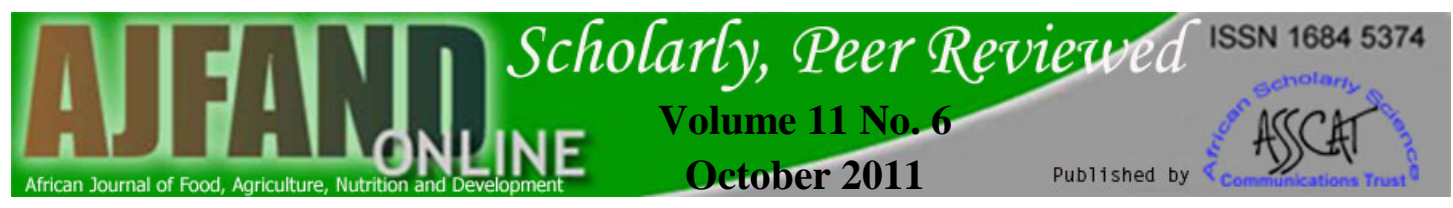

This scenario was piloted in summer 2010 with a group of 327 WishVast members over a two-week period. Within this period, WishVast successfully facilitated 37 jobs with 12 employers participating. A one-day arts festival was facilitated by forming a group of 18 local artists through WishVast. In this rural Kenyan economy, where the average daily income is about $\$ 1.20$, the artists collectively sold goods worth almost $\$ 820$ ( $\$ 45 /$ artist) at a one-day festival. Further field-testing of WishVast took place in Summer 2011.

The microfinance sector also presents some exciting opportunities for WishVast. Instead of viewing the microfinance industry as a binary relationship between microfinanciers and their clients, the industry can be viewed as a multi-actor system that includes informal lenders, rotating savings and credit associations, solidarity groups, savings and credit cooperatives, microfinance institutions and other players. The interdependence of the various actors and their relative success in the microfinance sector is of particular interest. This study provided significant insights on the importance of trust in the business relationships of women agro-entrepreneurs in Moshi and their reluctance to use formal credit systems. WishVast can play a role in building trust amongst these women and helping them leverage their social capital to get access to financial capital.

\section{CONCLUSION}

This study sheds light on the conceptions of trust surrounding social networks and entrepreneurial ventures in the African context. The goal of the study was not to study the role of trust in the networks, but rather, trust emerged as a major factor that affected the women's social networks and livelihoods. Development organizations in Africa, and in Tanzania in particular, would be well-advised to employ strategies for building trust amongst members of groups that are being encouraged to engage in entrepreneurial ventures. Thoughtful facilitation and expansion of social networks of the group is a strategy for developing social capital needed for their entrepreneurial initiatives to survive in the emerging economy. Within this context, cell phones have the potential to contribute significantly to social network expansion and to the complex process by which social, economic and political capital development occurs in rural areas of Africa. 


\section{Acknowledgements}

This study was funded by a Level-2 grant from the Social Science Research Institute at The Pennsylvania State University titled "How Well-Networked Are Rural Women Agro-Entrepreneurs in Northern Tanzania? A Social Network Analysis Pilot Project". We would like to acknowledge Dr. Gretchen Kuldau and Dr. Katelyn Willyerd for their help during the data gathering phase. Dr. Mary Marete and Mr. Rashmi Mehta assisted with translation and data analysis, and we are grateful to them. 


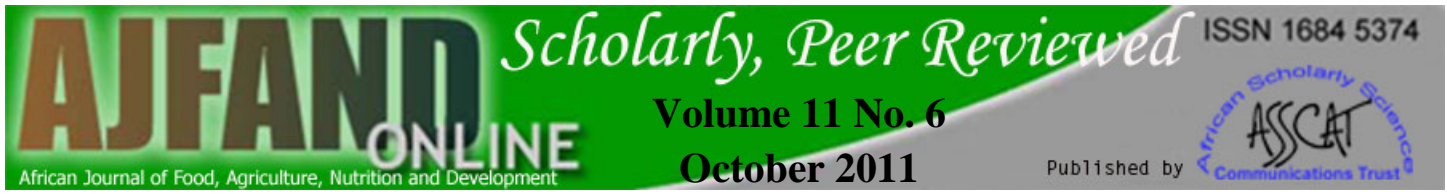

Table 1: Participant responses to trust-related questions on the PDA survey

\begin{tabular}{|c|c|c|c|}
\hline Trust-related Questions on the PDA survey & Yes & $\begin{array}{l}\text { No } \\
\%\end{array}$ & $\begin{array}{c}\text { Don’t } \\
\text { know } \\
\text { or Not } \\
\text { Sure } \\
\%\end{array}$ \\
\hline \multicolumn{4}{|l|}{ Cell phone-related questions answered by 26 respondents } \\
\hline 1.Do you own a cell phone & 62 & 38 & \\
\hline 2. Do you usually use a cell phone for business & 96 & 4 & \\
\hline \multicolumn{4}{|l|}{$\begin{array}{l}\text { Percentages based upon } 92 \text { business relationships assessed by the } 26 \\
\text { respondents }\end{array}$} \\
\hline 3. Do you trust each other? & 96 & 1 & 3 \\
\hline 4. Do you respect each other? & 100 & 0 & 0 \\
\hline 5. Do you believe you have an honest relationship with this person? & 95 & 1 & 4 \\
\hline 6. Is your relationship with this person reliable? & 90 & 3 & 7 \\
\hline 7. Is there something you are unsure of (afraid of) in this relationship? & & 97 & 3 \\
\hline $\begin{array}{l}\text { 8. Is this person good at recovering from business setbacks (e.g., credit } \\
\text { crunch or bankruptcy)? }\end{array}$ & 84 & 0 & 16 \\
\hline $\begin{array}{l}\text { 9. If you were this person's business partner, would you be willing to take } \\
\text { the same level of risk that he/she takes? }\end{array}$ & 55 & 35 & 10 \\
\hline $\begin{array}{l}\text { 10. Can you rely on each other to follow through on promises and } \\
\text { commitments? }\end{array}$ & 84 & 5 & 11 \\
\hline 11. Would you consider this person a community leader? & 67 & 19 & 14 \\
\hline 12. Would you say this person competes with your business? & 29 & 64 & 7 \\
\hline 13. Do you get advice for your business from this person? & 78 & 22 & 0 \\
\hline 14. Do you consider this person very much (similar to) like you? & 2 & 48 & 45 \\
\hline 15. Is this person good at recovering from business setbacks? & 84 & 0 & 16 \\
\hline 16. Is this individual open-minded to opinions that differ from his/her own? & 90 & 6 & 4 \\
\hline
\end{tabular}




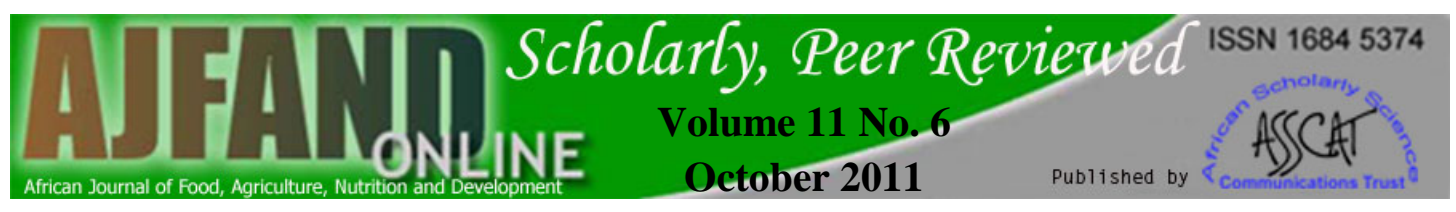

\section{REFERENCES}

1. Mehta K, Semali L and A Maretzki "Trust, Cell phones, Social Networks and Agricultural Entrepreneurship in Africa: A Dynamic Interdependence," African Journal of Food, Agriculture, Nutrition and Development, Vol 11, No. 6, 2011.

2. Stake R Qualitative research: studying how things work. New York: Gilford, 2010.

3. Creswell $\mathbf{J}$ Research design: qualitative, quantitative, and mixed methods approaches. Thousand Oaks, CA: Sage, 2003

4. Marshall C and G Rossman Designing Qualitative Research, 3rd ed. Thousand Oaks, CA: Sage Publications, 1999.

5. Baye $\mathbf{M}$, Morgan $\mathbf{J}$ and $\mathbf{P}$ Scholten "Information, Search, and Price Dispersion," in Handbook on Economics and Information Systems.: Elsevier, 2006.

6. Mehta K and L Semali "WishVast: Buiding Trust and Social Capital using Cell phones," in First International Symposium on Intelligent Mobile Technologies for Social Change (IMT4SC'09), Mragowo, Poland, 2009.

7. Garguilo S, Prindible M, Okello-Syata A and K Mehta "Labor hiring practices and produce supply chains in rural Kenya: the case for WishVast networking," International Journal for Service Learning in Engineering: Humanitarian Engineering and Social Entrepreneurship, Vol. 5, No. 1, 2010. 